\title{
Efficacy and safety of a low-sodium diet and spironolactone in patients with stage 1-3a chronic kidney disease: a pilot study
}

Hongmei Zhang* ${ }^{*}$, Bin Zhu, Liyang Chang, Xingxing Ye, Rongrong Tian, Luchen He, Dongrong Yu, Hongyu Chen and Yongjun Wang

\begin{abstract}
Background: Excessive salt intake is associated with the deterioration of chronic kidney disease (CKD). Aldosterone is also known as an independent risk factor for kidney injury. Dietary sodium intake acts as a main stimulator in aldosterone-mediated kidney injury. Hence, this study aimed to further investigate the renal protective effects and safety of a low-sodium diet in combination with spironolactone (SPL) in stage 1-3a CKD.

Methods: This single-center, SPL-blinded randomized controlled trial recruited patients with stage 1-3a CKD, randomized into three groups, low-sodium ( $3 \mathrm{~g} / \mathrm{d}$ salt) + placebo, medium-sodium ( $5 \mathrm{~g} / \mathrm{d}$ salt) $+\mathrm{SPL}$, and low-sodium $(3 \mathrm{~g} / \mathrm{d}$ salt $)+$ SPL. Patients received 12 weeks of intervention. The primary and secondary endpoints were $24-\mathrm{h}$ urine protein and estimated glomerular filtration rate (eGFR) at the end of the intervention, respectively.

Results: A total of 74 patients were analyzed eventually. Significantly decreased 24 -h urine protein was found in all three groups, from 0.37 to $0.23 \mathrm{~g} / \mathrm{d}(P=0.004)$ in the low-sodium+placebo group, from 0.44 to $0.29 \mathrm{~g} / \mathrm{d}(P=0.020)$ in the medium-sodium+SPL group, and from 0.35 to $0.31 \mathrm{~g} / \mathrm{d}(P=0.013)$ in the low-sodium $+\mathrm{SPL}$ group. There were no significant differences among the three groups in 24-h urine protein amount change after intervention from pretreatment values $(P=0.760$, ITT set). The results of the 24 -h urine protein by using PP set analysis was similar to the ITT set. No significant differences in eGFR, nutritional, metabolic, inflammatory, and other biomarkers were observed across all three groups $(P>0.05)$. No safety signal was observed.
\end{abstract}

Conclusion: No additional benefit was observed when SPL was prescribed to patients already on a low-sodium diet $(3.0 \mathrm{~g} / \mathrm{d})$. Still, small doses of SPL may benefit patients with poor sodium restriction. A combination of short-term lowdose SPL and ARB is safe for patients with stage 1-3a CKD, but blood potassium must be regularly monitored.

Trial registration: Name of the registry: Chinese clinical trial registry.

Trial registration number: ChiCTR1900026991.

Date of registration: Retrospectively registered 28 October 2019.

URL of trial registry record: http://www.chictr.org.cn/searchproj.aspx?title=\&officialname=\&subjectid=\&secon daryid=\&applier=\&studyleader=ðicalcommitteesanction=\&spo

Keywords: Low-sodium diet, Mineralocorticoid receptor antagonist, Chronic kidney disease, Spironolactone, Safety

\footnotetext{
*Correspondence: hzzhanghongmei@163.com

Department of Nephrology, Hangzhou TCM Hospital Affiliated to

Zhejiang Chinese Medical University, 453 Tiyuchang Road,

Hangzhou 310007, China
}

(C) The Author(s) 2022. Open Access This article is licensed under a Creative Commons Attribution 4.0 International License, which permits use, sharing, adaptation, distribution and reproduction in any medium or format, as long as you give appropriate credit to the original author(s) and the source, provide a link to the Creative Commons licence, and indicate if changes were made. The images or other third party material in this article are included in the article's Creative Commons licence, unless indicated otherwise in a credit line to the material. If material is not included in the article's Creative Commons licence and your intended use is not permitted by statutory regulation or exceeds the permitted use, you will need to obtain permission directly from the copyright holder. To view a copy of this licence, visit http://creativecommons.org/licenses/by/4.0/. The Creative Commons Public Domain Dedication waiver (http://creativeco mmons.org/publicdomain/zero/1.0/) applies to the data made available in this article, unless otherwise stated in a credit line to the data. 


\section{Background}

Chronic kidney disease (CKD) incidence is growing worldwide. The USRDS in 2018 revealed that CKD prevalence in adults reached $14.8 \%$ in 2013-2016 [1]. An epidemiological survey in China in 2012 indicated a CKD prevalence of $10.8 \%$ in adults over 18 years old [2]. For patients with CKD, early intervention is of great importance in controlling CKD progression and reducing mortality.

High salt intake is closely associated with the progression of CKD. When the urine sodium-to-creatinine ratio increases by $100 \mathrm{mmol} / \mathrm{L}$, the risk of CKD developing into end-stage renal disease (ESRD) increases by 1.61 times $[3,4]$. High salt intake leads to renal impairment in various ways, including increasing transforming growth factor (TGF)- $\beta 1$ production and enhancing oxidative stress and inflammatory response in the kidney [5-7]. Salt restriction reduces the effects of the above adverse factors, protecting the kidney and enhancing the antiproteinuric and antihypertensive effects of the reninangiotensin-aldosterone system (RAAS) antagonists such as angiotensin-converting enzyme inhibitors (ACEIs) and angiotensin II receptor blockers (ARBs) $[8,9]$. Heeg et al. [9] found that the effectiveness of the ACEI lisinopril in reducing albuminuria greatly depends on dietary sodium intake. The ACEI could not decrease albuminuria when sodium intake from food increased from 50 to $200 \mathrm{mmol} / \mathrm{d}$, while the decreasing effect of the ACEI on albuminuria recovered accordingly when sodium intake was reduced back to $50 \mathrm{mmol} / \mathrm{d}$. Vogt et al. [10] showed that proteinuria was reduced by $30 \%$ with losartan monotherapy alone. The reduction increased to $55 \%$ with the addition of salt restriction and to $56 \%$ with the addition of hydrochlorothiazide (HCT). The enhancing effects of salt restriction on ARB activity appeared similar to the addition of diuretics. Slagman et al. [11] reported that moderate dietary sodium restriction is more effective than the maximal dose of angiotensin receptor blocker in controlling proteinuria and blood pressure in patients with renal disease on a maximal dose of ACEI.

Aldosterone is a steroid hormone with mineralocorticoid activity. Historically, aldosterone has been shown to act mainly on the distal convoluted tubules of the kidney, regulating extracellular fluid capacity and potassium metabolism. However, in the past 20 years, studies have revealed an extensive role played by aldosterone [12-16]. Mounting evidence has been observed that aldosterone could affect the heart, blood vessels, the central nervous system, and the kidney, promoting vascular remodeling, collagen formation, and endothelial dysfunction $[15,16]$. These interactions play important roles in the pathophysiology of progressive renal dysfunction. Moreover, aldosterone/mineralocorticoid receptor (MR) could also damage podocytes. The enhanced MR effect is closely associated with protein leakage in the kidney [17-20], leading to CKD progression. With these new insights, mineralocorticoid receptor antagonists (MRAs) as a new treatment strategy are of particular interest. The discovery of the "aldosterone escape" phenomenon has made MRAs even more attractive for the treatment of CKD [21]. Multiple studies have evaluated the effects of MRAs on blood pressure control and proteinuria reduction, as well as their possible role in delaying the progression of CKD [14, 22, 23].

Aldosterone has been recognized as an independent risk factor mediating renal injury. However, another important parameter, sodium intake, cannot be ignored. More than 70 years ago, a pioneering study by Hans Selye showed that when desoxycorticosterone acetate (DOCA) is used in a rodent model of partial nephrectomy, improper salt intake (3\% saltwater) is required for inducing significant vasculitis changes in the heart and kidney [24]. A study of Dahl salt-sensitive rats also showed that high salt could induce oxidative stress and promote MR activation in the kidney [20]. These studies helped to understand the pathogenesis of MR-induced renal injury and establish reasonable treatment plans in CKD. Relevant research data also demonstrated that salt intake could affect the balance of beneficial and adverse effects of aldosterone [25]. In case of improper salt intake, acute administration of aldosterone reduces the levels of phosphorylated extracellular nitric oxide synthase (eNOS; vascular protection), increases the amounts of phosphorylated extracellular signal-regulated kinases 1 and 2 (ERK1/2) and protein kinase C (adverse to blood vessels). Conversely, salt intake reduction increases phosphorylated eNOS levels, reduces ERK1/2 and protein kinase $\mathrm{C}$ amounts, and minimizes or reverses the response to acute aldosterone administration. Plasma aldosterone levels unsuitable for intake of diet salt would amplify the above phenomenon. Hattori et al. [26] found that under low-salt conditions, MRA can completely suppress the expression of RAS-related genes in the myocardium of rats, alleviate myocardial oxidative stress and inflammatory response, and delay myocardial hypertrophy and fibrosis; meanwhile, MRA is only partly effective under high-salt conditions.

Based on the above, salt restriction is not only beneficial for renal protection but also can enhance the proteinuria-reducing effect of $\mathrm{ACEI} / \mathrm{ARB}$ while alleviating aldosterone-associated renal damage. So far, the main treatment delaying CKD progression and reducing the risk of end-stage renal disease is RAAS antagonists, including ACEI and ARB medications, as well as direct renin inhibitors. These medications are the current standard treatment options for CKD patients with 
proteinuria [27-31]. However, these medications only decrease the risk of proteinuria and ESRD by $20-30 \%$. Additional new therapies are needed given the huge cost burden of CKD as well as the associated physiological and psychological damage to patients [32,33]. Therefore, this study aims to investigate the renal protective effects and safety of a low-sodium diet combined with an MRA, spironolactone (SPL), in patients with stage 1-3a CKD.

\section{Methods}

\section{Participants}

Patients with stage 1-3a CKD were consecutively recruited from the outpatient Department of Nephrology in Hangzhou Hospital of Traditional Chinese Medicine from September 2014 to April 2017. According to K-DOQI guidelines [3, 4], the diagnostic criteria for CKD include: 1) renal injury (abnormal renal structure or function) for $\geq 3$ months, with or without glomerular filtration rate (GFR) decrease; 2) GFR $<60 \mathrm{ml} /\left(\mathrm{min} \cdot 1.73 \mathrm{~m}^{2}\right)$ for $\geq 3$ months, with or without evidence of renal injury.

Inclusion criteria were 1) primary chronic glomerular disease with positive urinary protein or albumin, 2) estimated GFR (eGFR) $\geq 45 \mathrm{ml} / \mathrm{min} / 1.73 \mathrm{~m}^{2}, 3$ ) aged 18-70 years, 4) no clinical evidence of acute injury, and 5) no mental disorder and ability to cooperate.

Exclusion criteria were 1) treatment with glucocorticoids, immunosuppressants, or nonsteroidal anti-inflammatory medications (NSAIDs) for more than one week in the past three months, 2) serious primary diseases affecting organs such as the heart, brain, lung, liver, or hematopoietic system, 3) malignant tumors, tuberculosis, and/ or other acute infectious diseases, 4) pregnancy, lactation or pregnancy planning in the near future in women, 5) hypersensitivity to MRAs such as SPL, and 6) participation in other medication-based clinical trials.

\section{Study design}

This was a single-center, double-blinded (SPL-blinded), randomized controlled trial. Patients were randomized into three groups and received the assigned intervention for 12 weeks. The random numbers were produced by means of a random number table in advance and were kept in an opaque envelope. After the intervention, blinding was uncovered. The current study was approved by the ethics committee of Hangzhou Hospital of Traditional Chinese Medicine (2013LL065), and written informed consent was obtained from the patients.

\section{Grouping and treatment}

Eligible patients were randomly assigned to three groups before the run-in period started. (1) Lowsodium+placebo group. Patients underwent strict control of daily dietary salt intake. The salt bag $(3 \mathrm{~g} / \mathrm{bag})$ and salt control spoon were provided, and the salt bag was replaced at the return visit. The appearance, size, weight, smell, and color of the placebo (Zhejiang Conba Pharmaceutical Co., Ltd) were the same as those of SPL, and it was administered orally at $40 \mathrm{mg}$ the first week and $20 \mathrm{mg}$ thereafter, once a day, $30 \mathrm{~min}$ after breakfast. (2) Medium-sodium+SPL group. The salt bag $(5 \mathrm{~g} / \mathrm{bag})$ and salt control spoon were provided, and SPL (20 mg tablets; Hangzhou Minsheng Pharmaceutical Co., Ltd) was taken. SPL was administered orally at $40 \mathrm{mg}$ the first week and $20 \mathrm{mg}$ thereafter, once a day, $30 \mathrm{~min}$ after breakfast. (3) Low-sodium +SPL group. Patients underwent strict control of daily dietary salt intake. Supplies and medications such as SPL were provided, and the salt bag was replaced at each visit. The intervention lasted for 12 weeks.

In the run-in period (0-4weeks), patients received training in optimal blood pressure and blood lipid control, salt intake assessment, and high-quality dietary choice with proper protein intake. Basic treatment during this period included the following: 1) Dietary guidance according to Chinese expert consensus on protein nutrition therapy for chronic kidney disease: dietary protein intake is $0.8 \mathrm{~g} / \mathrm{kg} / \mathrm{d}-1.0 \mathrm{~g} / \mathrm{kg} / \mathrm{d}$ with $50 \%$ high biological value protein, and dietary energy intake is $30-35 \mathrm{kcal} /$ $\mathrm{kg} / \mathrm{d}$, and education of adult patients for low-fat diet during treatment. 2) Blood pressure control: the ARB dose was stable for more than 3 months at the time of enrollment and maintained throughout the study. Among the patients, $79.7 \%$ used ARBs (Irbesartan at $75-150 \mathrm{mg}$ or Cozaar at $50-100 \mathrm{mg}$ ), $10.8 \%$ used calcium channel blocker (CCB), and 1 patient used $\beta$ blocker. $\mathrm{CCB}$ and other antihypertensive medications were added to patients showing increased blood pressure during the study. However, the ARB dosage remained unchanged. No diuretics were used in the study. Target blood pressure was below $130 / 80 \mathrm{mmHg}$.

All patients received routine diet and nutrition guidance to correctly record diet diaries (including food types and quantities), and regular outpatient follow-up was performed. During the study period, patients were visited by assigned investigators, who distributed medications, recovered medications, and exchanged salt bags to ensure patient compliance and safety.

\section{Biomarker assessment}

The follow-up visits occurred at $0,4,8$, and 12 weeks after treatment initiation. During each follow-up visit, blood pressure measurements and laboratory tests (blood and urine) were performed. Self-reported dietary intake and adverse events were documented. During visits at 0 and 12 weeks, electrocardiogram (ECG) and renal ultrasound were also performed as a safety assessment. 
The primary endpoint was 24-h urine protein at the end of the intervention in the intent-to-treat (ITT) set and per-protocol (PP) set. The secondary endpoint was eGFR at the end of the intervention and was analyzed in the PP set. Nutritional, metabolic, and inflammatory biomarkers including serum albumin (ALB), serum pre-albumin (PA), blood uric acid (UA), total cholesterol (TC), triglycerides (TG), low-density lipoproteincholesterol (LDL-C), and C-reactive protein (CRP) were checked regularly. Besides ECG and renal ultrasound, safety indicators including blood routine, liver function, serum creatinine $(\mathrm{Scr})$, blood urea nitrogen (BUN), and blood potassium were monitored regularly. Adverse events such as gynecomastia and sexual dysfunction were also monitored. Other indicators included 24-h urinary sodium (24h-UNa), urine potassium (UK), blood pressure, and estimated dietary protein intake (eDPI) [34]. $24 \mathrm{~h}-\mathrm{UNa}$ were monitored at $0,4,8$, and 12 weeks.

\section{Statistical analysis}

The last observation carried forward (LOCF) and a regression-based multiple imputation procedure were used to manage the missing data. Data were analyzed with SPSS 19.0 (IBM Corp, Armonk, NY, USA). Continuous variables with a normal distribution were presented as means \pm standard deviation (SD) and compared by one-way analysis of variance (ANOVA) among three groups. Paired t-test was used to compare results between two time points in each group. Continuous variables with skewed distribution were presented as median and interquartile range and were compared by the Kruskal-Wallis test among three groups. The Wilcoxon rank-sum test was used to compare results between two time points in each group. Categorical variables were presented as frequency and percentage and were compared by Pearson Chi-squared test. $P<0.05$ was considered statistically significant.

\section{Results}

\section{Patient disposition and characteristics}

We assessed 452 patients for eligibility. Of these, 368 were excluded because of no signed informed consent $(n=42)$, current steroid or immunosuppressant therapy $(n=300)$, advanced tumors $(n=5)$, remote residence inconvenient for review $(n=11)$, and other reasons $(n=10)$. A total of 84 patients were randomized into three groups with 28 patients per group and started the run-in period, with seven withdrawing. Finally, 77 patients started the intervention period, including 27, 26, and 24 in the low-sodium+placebo, medium-sodium +SPL, and lowsodium+SPL groups, respectively. During the intervention period, two patients and one patient withdrew from the medium-sodium + SPL group and low-sodium + SPL group, respectively. A total of 74 patients completed the 12 weeks of intervention (Fig. 1).

These 74 patients consisted of 39 males and 35 females. Their diagnoses included: 40 patients with IgA nephropathy, two patients with membranous nephropathy, two patients with mesangial proliferative glomerulonephritis, one patient with minimal change disease, and 29 patients with chronic glomerulonephritis not otherwise specified. Sixty-three patients were stage 1-2 CKD, and 11 patients were stage $3 \mathrm{a}$ CKD. There were two patients in the lowsodium +SPL group who had diabetes (one patient had a history of diabetes for five years and another for three years). There were no significant differences in sex, age, body mass index (BMI), 24-h urine protein, eGFR, Scr, BUN, blood pressure, nutritional, metabolic, inflammatory, and other biomarkers among the three groups at baseline (Table 1).

As for the salt levels of patients in this study, the median (range) of 24h-UNa levels at 4, 8, 12 weeks fluctuated between $115(93,150) \mathrm{mmol} / \mathrm{d}$ and $125(91,156) \mathrm{mmol} / \mathrm{d}$, $145(110,217) \mathrm{mmol} / \mathrm{d}$ and $153(117,190) \mathrm{mmol} / \mathrm{d}$, and $114(86,173) \mathrm{mmol} / \mathrm{d}$ and $126(94,169) \mathrm{mmol} / \mathrm{d}$ in the low-sodium+placebo, medium-sodium + SPL, and low-sodium+SPL groups, respectively. Supplementary Table S1 shows that there were no differences in $24 \mathrm{~h}-\mathrm{UNa}$ among the three groups at baseline $(P=0.598)$, but that the 24h-UNA was significantly higher in the medium-sodium + SPL group compared with the lowsodium+placebo $(P=0.024)$ and low-sodium + SPL group $(P=0.007)$. Supplementary Table $\mathrm{S} 2$ shows that there were no differences in $\mathrm{Una} / \mathrm{Cr}$ among the three groups at baseline $(P=0.303)$, but that the UNA/Cr was significantly higher in the medium-sodium + SPL group compared with the low-sodium +placebo $(P=0.011)$ and low-sodium + SPL group $(P=0.006)$.

\section{Efficacy}

After 12 weeks of intervention, as the primary endpoint (ITT set), 24-h urine protein decreased from $0.37(0.23$, $0.70)$ to $0.23(0.16,0.51)$ in the low-sodium+placebo group $(P=0.004)$. The $24-\mathrm{h}$ urine protein decreased from $0.44(0.33,0.71)$ to $0.29(0.17,0.50)$ in the mediumsodium + SPL group $(P=0.020)$. The 24 -h urine protein decreased from $0.35(0.26,0.73)$ to $0.31(0.22,0.60)$ in the low-sodium + SPL group $(P=0.013)$. There were no significant differences among the three groups in 24-h urine protein amount changes after intervention from pretreatment values $(P=0.760)$, as shown in Table 2 .

In the low-sodium+placebo group, the 24-h urine protein to creatine ratio was decreased from 30.54 (18.83, $77.38)$ to $25.40(14.12,50.71)(P=0.012)$. Meanwhile, the 24-h urine protein to creatine ratios were decreased from $54.00(28.77,81.30)$ to $24.72(18.49,44.10)$, and 


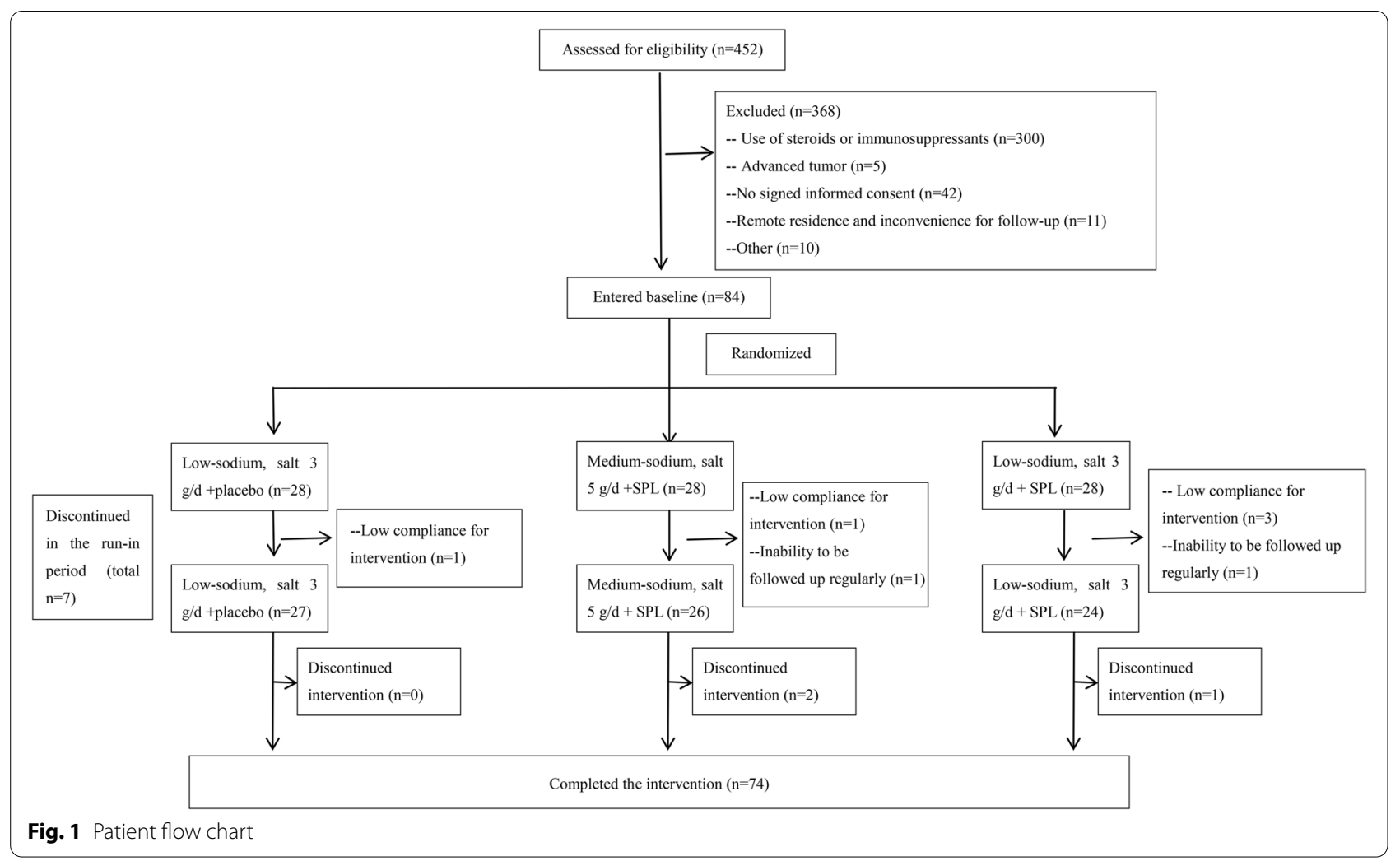

from $33.12(25.90,58.68)$ to $29.20(15.69,62.39)$ in the medium-sodium + SPL $(P=0.011)$ and low-sodium + SPL $(P=0.026)$ groups, respectively. As for the changes preand post-intervention, there were no differences among the three groups $(P=0.118)$. The secondary endpoint eGFR also showed no significant differences among the three groups. In addition, the results of the 24-h urine protein by using PP set analysis was similar to the ITT set (PP set; Table 3).

\section{Safety and other indexes}

During the intervention period of this clinical trial, hyperkalemia was not observed in any of the three groups. Average blood potassium levels ranged $4.26 \pm 0.28 \mathrm{mmol} / \mathrm{L}$ in the low-sodium+placebo group, $4.29 \pm 0.26 \mathrm{mmol} / \mathrm{L}$ in the medium-sodium $+\mathrm{SPL}$ group and $4.35 \pm 0.32 \mathrm{mmol} / \mathrm{L}$ in the low-sodium $+\mathrm{SPL}$ group $(P>0.05)$. However, three patients (one patient with stage 2 CKD and two patients with stage 3 a CKD, respectively) with increased blood potassium levels were observed in the low-sodium +SPL group. The range of blood potassium increase was $5.18-5.24 \mathrm{mmol} / \mathrm{L}$. Dietary reports revealed that these three patients ate high-potassium foods. Their blood potassium decreased to 4.46$4.87 \mathrm{mmol} / \mathrm{L}$ after dietary guidance was provided without the need for any medication adjustments.
No gynecomastia or sexual dysfunction was observed in patients in the medium-sodium +SPL group and lowsodium + SPL group. No significant abnormal changes in blood routine, liver function, ECG parameters, and other routine safety indicators were observed in any patient. In addition, no progressive renal dysfunction (eGFR decreased by $30 \%$ ) or all-cause death was observed during the study.

During the intervention period, nutritional, metabolic, and inflammatory markers, as well as blood pressure, were stable in all three groups. ALB levels in the lowsodium+placebo group were decreased after 12 weeks of intervention, but all fell within the normal range. TC and LDL-C levels in the low-sodium+placebo group decreased significantly (both $p=0.001$ ), while LDL-C level in the low-sodium+placebo group after the intervention was significantly lower than the other two groups (both $p<0.05$ ). The SBP and DBP all showed a decrease after intervention with no significant statistical difference among the three groups (Table 4).

\section{Discussion}

The key observations of this study are as follows. First, no further benefit exists from the addition of SPL in patients with a low sodium diet $(3.0 \mathrm{~g} / \mathrm{d}$ salt). Second, small doses of SPL may benefit patients with poor sodium restriction. 
Table 1 Baseline characteristics

\begin{tabular}{|c|c|c|c|c|}
\hline Parameters & $\begin{array}{l}\text { Low-sodium + placebo } \\
(n=27)\end{array}$ & $\begin{array}{l}\text { Medium-sodium }+ \text { SPL } \\
(n=24)\end{array}$ & Low-sodium+SPL $(n=23)$ & $P$ \\
\hline Male, N (\%) & $14(52 \%)$ & $9(38 \%)$ & $16(70 \%)$ & 0.763 \\
\hline Age (years) & $42.44 \pm 11.52$ & $39.71 \pm 9.68$ & $43.00 \pm 12.65$ & 0.563 \\
\hline CKD stages, N (\%) & & & & 0.967 \\
\hline Stage 1 & $16(59 \%)$ & $15(62 \%)$ & $13(57 \%)$ & \\
\hline Stage 2 & $7(26 \%)$ & $5(21 \%)$ & $7(30 \%)$ & \\
\hline Stage 3a & $4(15 \%)$ & $4(17 \%)$ & $3(13 \%)$ & \\
\hline Renal diagnosis, N (\%) & & & & 0.791 \\
\hline IgA nephropathy & $13(48 \%)$ & $14(58 \%)$ & $13(57 \%)$ & \\
\hline MsPGN & 0 & $1(4 \%)$ & $1(4 \%)$ & \\
\hline MN & 0 & $1(4 \%)$ & $1(4 \%)$ & \\
\hline MCD & $1(4 \%)$ & 0 & 0 & \\
\hline No renal biopsy & $13(48 \%)$ & $8(33 \%)$ & $8(35 \%)$ & \\
\hline \multicolumn{5}{|l|}{ Antihypertensive drugs, N (\%) } \\
\hline ARB & $20(74 \%)$ & $19(79 \%)$ & $20(87 \%)$ & 0.548 \\
\hline CCB & $3(11 \%)$ & $2(8 \%)$ & $3(13 \%)$ & 0.901 \\
\hline$\beta$-blocker & 0 & 1 & 0 & \\
\hline BMI $\left(\mathrm{kg} / \mathrm{m}^{2}\right)$ & $24.16 \pm 3.42$ & $23.50 \pm 3.60$ & $23.45 \pm 3.65$ & 0.728 \\
\hline TC (mmol/L) & $4.57 \pm 0.86$ & $4.56 \pm 1.07$ & $4.54 \pm 0.77$ & 0.993 \\
\hline $\mathrm{TG}(\mathrm{mmol} / \mathrm{L})$ & $1.38 \pm 0.62$ & $2.30 \pm 2.06$ & $1.75 \pm 0.90$ & 0.053 \\
\hline LDL-C (mmol/L) & $2.57 \pm 0.56$ & $2.83 \pm 0.78$ & $2.76 \pm 0.70$ & 0.364 \\
\hline SBP (mmHg) & $118.15 \pm 9.81$ & $119.29 \pm 11.51$ & $122.30 \pm 11.85$ & 0.403 \\
\hline $\mathrm{DBP}(\mathrm{mmHg})$ & $72.30 \pm 7.31$ & $72.88 \pm 9.13$ & $72.87 \pm 10.46$ & 0.965 \\
\hline Blood potassium (mmol/L) & $4.34 \pm 0.39$ & $4.22 \pm 0.39$ & $4.23 \pm 0.40$ & 0.476 \\
\hline UNa $(\mathrm{mmol} / \mathrm{d})$ & $138.48 \pm 60.92$ & $157.70 \pm 70.00$ & $154.68 \pm 87.55$ & 0.598 \\
\hline UK (mmol/d) & $54.29 \pm 17.61$ & $51.25 \pm 13.57$ & $51.31 \pm 11.32$ & 0.700 \\
\hline 24-h urine protein $(\mathrm{g} / \mathrm{d})$ & $0.37(0.23,0.67)$ & $0.41(0.32,0.64)$ & $0.35(0.28,0.56)$ & 0.482 \\
\hline 24-h urine creatinine $(\mathrm{mmol} / \mathrm{d})$ & $10.91(9.03,13.03)$ & $9.41(7.13,11.91)$ & $11.20(8.99,13.14)$ & 0.128 \\
\hline $\begin{array}{l}\text { 24-h urine protein to creatinine ratio }(\mathrm{g} / \\
\mathrm{mol} \text { ) }\end{array}$ & $30.22(19.00,69.46)$ & $50.88(27.91,73.03)$ & $34.89(26.60,52.94)$ & 0.342 \\
\hline eGFR (ml/min/1.73m²) & $93.15 \pm 30.94$ & $98.18 \pm 30.75$ & $94.48 \pm 27.11$ & 0.826 \\
\hline $\operatorname{Scr}(\mu \mathrm{mol} / \mathrm{L})$ & $81.66 \pm 28.61$ & $76.42 \pm 30.90$ & $83.43 \pm 28.73$ & 0.694 \\
\hline BUN (mmol/L) & $6.02 \pm 1.62$ & $5.66 \pm 1.82$ & $5.78 \pm 2.03$ & 0.767 \\
\hline Alb (g/L) & $43.66 \pm 2.26$ & $42.78 \pm 2.71$ & $42.77 \pm 2.64$ & 0.356 \\
\hline $\mathrm{PA}(\mathrm{g} / \mathrm{L})$ & $0.33 \pm 0.07$ & $0.34 \pm 0.06$ & $0.35 \pm 0.09$ & 0.622 \\
\hline UA ( $\mu \mathrm{mol} / \mathrm{L})$ & $374.90 \pm 75.84$ & $360.29 \pm 83.86$ & $378.09 \pm 75.51$ & 0.705 \\
\hline CRP (mg/L) & $1.76 \pm 1.98$ & $1.26 \pm 1.01$ & $1.51 \pm 1.56$ & 0.547 \\
\hline eDPI (g/kg/d) & $1.06 \pm 0.21$ & $1.00 \pm 0.26$ & $1.08 \pm 0.23$ & 0.465 \\
\hline
\end{tabular}

Note: Data at the end of the run-in period were taken as baseline values

$S P L$ spironolactone, MsPGN mesangial proliferative glomerulonephritis, $M N$ membranous nephropathy, $M C D$ minimal change disease, $A R B$ angiotensin II receptor blocker, $C C B$ calcium channel blocker, $B M I$ body mass index, $T C$ total cholesterol, $T G$ triglycerides, $L D L-C$ low density lipoprotein-cholesterol, SBP systolic blood pressure, $D B P$ diastolic blood pressure, UNa urine sodium, UK urine potassium, eGFR estimated glomerular filtration rate, Scr serum creatinine, $B U N$ blood urea nitrogen, $A / b$ albumin, $P A$ pre-albumin, UA uric acid, CRP C-reactive protein, $e D P I$ estimated daily protein intake

Under the condition of basic treatment, 24-h urine protein to creatine ratios were decreased significantly in all three groups of ITT or PP set after 12 weeks of intervention, but there were no significant differences among the three groups $(P>0.05)$. These results suggested that sodium control and/or SPL might have renal protective effects in patients with stage 1-3a CKD.

Few clinical studies have assessed the relationship between salt intake and MRA administration, and a literature review found no related randomized controlled 
Table 2 Clinical parameters before and after intervention (ITT set)

\begin{tabular}{|c|c|c|c|c|c|}
\hline Parameters & & $\begin{array}{l}\text { Low-sodium+placebo } \\
(n=28)\end{array}$ & $\begin{array}{l}\text { Medium-sodium }+S P L \\
(n=28)\end{array}$ & $\begin{array}{l}\text { Low-sodium +SPL } \\
(n=28)\end{array}$ & Pamong groups \\
\hline \multirow{4}{*}{$\begin{array}{l}\text { Primary } \\
\text { endpoint 24-h } \\
\text { urine protein } \\
(\mathrm{g} / \mathrm{d})\end{array}$} & Before intervention & $0.37(0.23,0.70)$ & $0.44(0.33,0.71)$ & $0.35(0.26,0.73)$ & 0.365 \\
\hline & At 12 weeks & $0.23(0.16,0.51)$ & $0.29(0.17,0.50)$ & $0.31(0.22,0.60)$ & 0.791 \\
\hline & $\begin{array}{l}\text { Change between pre- and } \\
\text { post- intervention }\end{array}$ & $-0.06(-0.24,0)$ & $-0.17(-0.25,-0.01)$ & $-0.12(-0.27,0.05)$ & 0.760 \\
\hline & P within group & 0.004 & 0.020 & 0.013 & \\
\hline \multirow{4}{*}{$\begin{array}{l}\text { 24-h urine } \\
\text { protein to cre- } \\
\text { atinine ratio } \\
(\mathrm{g} / \mathrm{mol})\end{array}$} & Before intervention & $30.54(18.83,77.38)$ & $\begin{array}{l}54.00(28.77, \\
81.30)\end{array}$ & $\begin{array}{l}33.12(25.90, \\
58.68)\end{array}$ & 0.248 \\
\hline & At 12 weeks & $25.40(14.12,50.71)$ & $24.72(18.49,44.10)$ & $29.20(15.69,62.39)$ & 0.949 \\
\hline & $\begin{array}{l}\text { Change between pre- and } \\
\text { post-intervention }\end{array}$ & $-3.72(-16.42,1.04)$ & $-15.85(-41.40,-3.27)$ & $-11.70(-22.88,10.92)$ & 0.118 \\
\hline & P within group & 0.012 & 0.011 & 0.026 & \\
\hline
\end{tabular}

Note: Data are mean:standard deviation or median (interquartile range)

eGFR estimated glomerular filtration rate

Table 3 Clinical parameters before and after intervention (PP set)

\begin{tabular}{|c|c|c|c|c|c|}
\hline Parameters & & $\begin{array}{l}\text { Low-sodium+placebo } \\
(n=27)\end{array}$ & $\begin{array}{l}\text { Medium-sodium }+S P L \\
(n=24)\end{array}$ & $\begin{array}{l}\text { Low-sodium +SPL } \\
(n=23)\end{array}$ & Pamong groups \\
\hline \multirow{4}{*}{$\begin{array}{l}\text { Primary endpoint 24-h } \\
\text { urine protein }(\mathrm{g} / \mathrm{d})\end{array}$} & Before intervention & $0.37(0.23,0.67)$ & $0.41(0.32,0.64)$ & $0.35(0.28,0.56)$ & 0.482 \\
\hline & At 12 weeks & $0.21(0.16,0.50)$ & $0.27(0.15,0.41)$ & $0.30(0.17,0.60)$ & 0.827 \\
\hline & $\begin{array}{l}\text { Change between pre- } \\
\text { and post- intervention }\end{array}$ & $-0.06(-0.24,0)$ & $-0.17(-0.25,-0.01)$ & $-0.12(-0.27,0.05)$ & 0.721 \\
\hline & P within the group & 0.004 & 0.009 & 0.021 & \\
\hline \multirow{4}{*}{$\begin{array}{l}24 \mathrm{~h} \text { urine protein to } \\
\text { creatinine ratio }(\mathrm{g} / \mathrm{mol})\end{array}$} & Before intervention & $30.22(19.00,69.46)$ & $50.88(27.91,73.03)$ & $34.89(26.60,52.94)$ & 0.342 \\
\hline & At 12 weeks & $24.62(14.02,48.32)$ & $23.77(17.36,40.31)$ & $30.00(15.49,56.97)$ & 0.957 \\
\hline & $\begin{array}{l}\text { Change between pre- } \\
\text { and post- intervention }\end{array}$ & $-3.72(-16.42,1.04)$ & $-15.85(-41.40,-3.27)$ & $-11.70(-22.88,10.92)$ & 0.112 \\
\hline & P within the group & 0.030 & 0.012 & 0.046 & \\
\hline \multirow{4}{*}{$\begin{array}{l}\text { Secondary endpoint } \\
\text { eGFR (ml/min/1.73m²) }\end{array}$} & Before intervention & $93.15 \pm 30.94$ & $98.18 \pm 30.75$ & $94.48 \pm 27.11$ & 0.826 \\
\hline & 12 weeks & $96.56 \pm 31.20$ & $93.50 \pm 25.36$ & $94.35 \pm 28.99$ & 0.925 \\
\hline & $\begin{array}{l}\text { Change between pre- } \\
\text { and post-intervention } \\
\text { [95\% confidence } \\
\text { interval] }\end{array}$ & $3.41[-0.57,7.39]$ & $-4.68[-12.10,2.74]$ & $-0.13[-3.90,3.64]$ & 0.082 \\
\hline & P within the group & 0.090 & 0.205 & 0.944 & \\
\hline
\end{tabular}

Note: Data are mean:standard deviation or median (interquartile range)

eGFR estimated glomerular filtration rate

trials. A post hoc analysis of MRA efficacy stratified by urinary sodium excretion of the Eplerenone Combination Versus Conventional Agents to Lower Blood Pressure on Urinary Antialbuminuric Treatment Effect (EVALUATE) trial was recently conducted [35]. In this study, the population included patients with CKD and hypertension but without diabetes, and the basic treatment was ACEI and/or ARB. The results showed that eplerenone-treated patients in the highest sodium excretion tertile exhibited significantly greater reduction in urinary albumin to creatinine ratio (UACR) compared with the placebo subjects in the same tertile $(-22.5 \%$ vs. $+21.8 \%, p=0.02)$. While this disparity was not observed neither in the lowest tertile $(-10.2 \%$ vs. $-0.84 \%, p=0.65)$ nor in the middle tertile $(-19.5 \%$ vs. $+9.5 \%, p=0.22$ ). These authors concluded that the therapeutic effect of MRA is related to salt intake. In patients with high urinary sodium, the antiproteinuric 
Table 4 Other indicators before and after intervention

\begin{tabular}{|c|c|c|c|c|c|}
\hline Parameters & & $\begin{array}{l}\text { Low-sodium+placebo } \\
(n=27)\end{array}$ & $\begin{array}{l}\text { Medium-sodium }+ \text { SPL } \\
(n=24)\end{array}$ & $\begin{array}{l}\text { Low-sodium +SPL } \\
(n=23)\end{array}$ & $P$ \\
\hline \multirow[t]{3}{*}{ ALB (g/L) } & Before Intervention & $43.66 \pm 2.26$ & $42.78 \pm 2.71$ & $42.77 \pm 2.64$ & 0.356 \\
\hline & After Intervention & $42.60 \pm 2.75$ & $43.07 \pm 1.97$ & $43.12 \pm 2.79$ & 0.725 \\
\hline & $P$ & 0.018 & 0.677 & 0.401 & \\
\hline \multirow[t]{3}{*}{$\mathrm{PA}(\mathrm{g} / \mathrm{L})$} & Before Intervention & $0.33 \pm 0.07$ & $0.34 \pm 0.06$ & $0.35 \pm 0.09$ & 0.622 \\
\hline & After Intervention & $0.33 \pm 0.06$ & $0.33 \pm 0.06$ & $0.35 \pm 0.08$ & 0.317 \\
\hline & $P$ & 0.824 & 0.214 & 0.843 & \\
\hline \multirow[t]{3}{*}{ eDPI (g/kg/d) } & Before Intervention & $1.06 \pm 0.21$ & $1.00 \pm 0.26$ & $1.08 \pm 0.23$ & 0.465 \\
\hline & After Intervention & $1.02 \pm 0.25$ & $1.05 \pm 0.16$ & $1.09 \pm 0.17$ & 0.385 \\
\hline & $P$ & 0.377 & 0.413 & 0.770 & \\
\hline \multirow[t]{3}{*}{$\operatorname{Scr}(\mu \mathrm{mol} / \mathrm{L})$} & Before Intervention & $81.66 \pm 28.61$ & $76.42 \pm 30.90$ & $83.43 \pm 28.73$ & 0.694 \\
\hline & After Intervention & $77.68 \pm 23.50$ & $77.42 \pm 29.20$ & $83.96 \pm 30.40$ & 0.655 \\
\hline & $P$ & 0.020 & 0.696 & 0.780 & \\
\hline \multirow[t]{3}{*}{ BUN (mmol/L) } & Before Intervention & $6.02 \pm 1.62$ & $5.66 \pm 1.82$ & $5.78 \pm 2.03$ & 0.767 \\
\hline & After Intervention & $5.73 \pm 2.07$ & $5.97 \pm 1.30$ & $6.21 \pm 2.20$ & 0.666 \\
\hline & $P$ & 0.206 & 0.315 & 0.055 & \\
\hline \multirow[t]{3}{*}{ UA ( $\mu \mathrm{mol} / \mathrm{L})$} & Before Intervention & $374.90 \pm 75.84$ & $360.29 \pm 83.86$ & $378.09 \pm 75.51$ & 0.705 \\
\hline & After Intervention & $374.38 \pm 82.16$ & $385.08 \pm 76.40$ & $365.13 \pm 88.35$ & 0.709 \\
\hline & $P$ & 0.964 & 0.159 & 0.457 & \\
\hline \multirow[t]{3}{*}{$\mathrm{TC}(\mathrm{mmol} / \mathrm{L})$} & Before Intervention & $4.57 \pm 0.86$ & $4.56 \pm 1.07$ & $4.54 \pm 0.77$ & 0.993 \\
\hline & After Intervention & $4.15 \pm 0.73$ & $4.68 \pm 0.95$ & $4.50 \pm 0.93$ & 0.092 \\
\hline & $P$ & 0.001 & 0.668 & 0.824 & \\
\hline \multirow[t]{3}{*}{ TG (mmol/L) } & Before Intervention & $1.38 \pm 0.62$ & $2.30 \pm 2.06$ & $1.75 \pm 0.90$ & 0.053 \\
\hline & After Intervention & $1.25 \pm 0.60$ & $1.68 \pm 0.94$ & $1.72 \pm 0.76$ & 0.060 \\
\hline & $P$ & 0.201 & 0.068 & 0.852 & \\
\hline \multirow[t]{3}{*}{ LDL-C (mmol/L) } & Before Intervention & $2.57 \pm 0.56$ & $2.83 \pm 0.78$ & $2.76 \pm 0.70$ & 0.364 \\
\hline & After Intervention & $\left.2.19 \pm 0.59^{a} \cdot b\right)$ & $2.82 \pm 0.75$ & $2.59 \pm 0.71$ & 0.006 \\
\hline & $P$ & 0.001 & 0.881 & 0.249 & \\
\hline \multirow[t]{3}{*}{$\mathrm{CRP}(\mathrm{mg} / \mathrm{L})$} & Before Intervention & $1.76 \pm 1.98$ & $1.26 \pm 1.01$ & $1.51 \pm 1.56$ & 0.547 \\
\hline & After Intervention & $1.54 \pm 1.86$ & $1.42 \pm 1.15$ & $1.67 \pm 2.30$ & 0.890 \\
\hline & $P$ & 0.588 & 0.564 & 0.613 & \\
\hline \multirow[t]{3}{*}{ SBP (mmHg) } & Before Intervention & $118.15 \pm 9.81$ & $119.29 \pm 11.51$ & $122.30 \pm 11.85$ & 0.403 \\
\hline & After Intervention & $116.52 \pm 9.69$ & $113.46 \pm 11.98$ & $117.65 \pm 9.73$ & 0.367 \\
\hline & $P$ & 0.413 & 0.003 & 0.086 & \\
\hline \multirow[t]{3}{*}{$\mathrm{DBP}(\mathrm{mmHg})$} & Before Intervention & $72.30 \pm 7.31$ & $72.88 \pm 9.13$ & $72.87 \pm 10.46$ & 0.965 \\
\hline & After Intervention & $71.52 \pm 7.76$ & $69.42 \pm 8.12$ & $70.39 \pm 9.17$ & 0.668 \\
\hline & $P$ & 0.582 & 0.029 & 0.209 & \\
\hline
\end{tabular}

a) $P<0.05$, compared with medium-sodium $(5 \mathrm{~g} / \mathrm{d}$ salt $)+\mathrm{SPL}$

b) $P<0.05$, compared with low-sodium ( $3 \mathrm{~g} / \mathrm{d}$ salt $)+S P L$

Data are mean \pm standard deviation. $A L B$ albumin, $P A$ pre-albumin, $e D P I$ estimated daily protein intake, $S c r$ serum creatinine, $B U N$ blood urea nitrogen, $U A$ uric acid, $C R P C$-reactive protein, $S B P$ systolic blood pressure, $D B P$ diastolic blood pressure

effect of MRA was more significant than that of a placebo, while in patients with low urinary sodium, the antiproteinuric effect was not significantly different [35]. This conclusion corroborated our findings. The possible mechanism is as follows. Salt loading could enhance the renal MR activation pathway by activating Rac1 without increasing circulating aldosterone, causing hypertension and renal damage; meanwhile, MRA blocks this pathway, inhibits high-salt intake associated renal injury, overcomes salt-associated resistance to routine RAS blockade treatment, and plays a role of renal protection [36]. Similar results have been found in patients with refractory hypertension. The higher the salt intake level, the greater the blood 
pressure response to SPL treatment, suggesting that MRA could antagonize the increase of blood pressure caused by high salt intake [37].

As a simple and cost-effective treatment, dietary salt restriction delays CKD progression. However, patients with CKD show poor adherence to a low-salt diet in their daily life. Data showed that average $24 \mathrm{~h}$ urine sodium excretion in patients with CKD ranges between 144 and $200 \mathrm{mmol} / \mathrm{d}$ [3, 38-41]. It is challenging to achieve salt restriction even in clinical trials. Average daily salt consumption is $9-13 \mathrm{~g} / \mathrm{d}$ in reported CKD clinical studies up to now [42]. Adding SPL to the treatment regimen may be a potential new strategy in patients with CKD that are unable to achieve the ideal salt restriction goal.

Hyperkalemia is the main adverse side effect in patients taking MRA, especially in combination with ACEI and/ or ARB. Previous studies have shown that the risk of hyperkalemia after treatment with MRA combined with ACEI and/or ARB is elevated compared with ACEI and/ or ARB alone [22, 23, 43-46]. Epstein et al. carefully evaluated hyperkalemia incidence in 268 patients, and blood potassium levels showed no significant change in MRA combined with ACEI compared to ACEI alone [47]. During the 12 week intervention period in this study, there was no hyperkalemia in medium-sodium +SPL and low-sodium +SPL groups. Even in patients with ESRD, previous research has suggested that treatment is safe provided that the medication indication is accurate and strict monitoring parameters are applied [48].

Gynecomastia resulting from the combination of aldosterone with androgen and progesterone receptors is often reported as a side effect of SPL, thereby limiting its clinical usefulness. In the RALES study, gynecomastia incidence in patients treated with SPL was $9 \%$ versus $1 \%$ in the placebo arm [49]. The use of the selective MRA EPL could reduce these risks and other side effects [50]. In addition, finerenone, a nonsteroidal, selective mineralocorticoid receptor antagonist, reduced the risks of CKD progression and cardiovascular events in patients with CKD and type 2 diabetes compared with placebo in the FIDELIO-DKD trial; meanwhile, the overall rates of adverse events were similar in both groups [51]. In this study, the non-selective MRA SPL was administered at $20 \mathrm{mg} /$ day, and no significant adverse events were found in the medium-sodium+SPL and low-sodium+SPL groups throughout the study.

Several limitations in this clinical trial are noted as follows. First, although this was a prospective, randomized controlled study (medication administration was performed in a blinded manner), salt intake could not be blinded. Secondly, based on ethical principles, a high salt group (oral salt tablet) was not established in this study due to the proven high salt-associated renal damage. Thirdly, low-dose ARB was administered to most patients, and the independent effect of salt restriction alone or salt restriction combined with MRA could not be explained. Fourthly, this was a single-center pilot study, with a relatively small sample size, relatively normal kidney function, and short follow-up, which limited the evaluation of the efficacy and long-term safety profile. Fifthly, long-term data for various endpoints were not obtained. Based on these limitations, larger multicenter clinical trials with longer follow-up are required to further evaluate the effects and safety of sodium restriction and MRAs.

\section{Conclusion}

Under low sodium intake conditions, ARB combined with SPL has no additional benefits on lowering urine protein compared with ARB alone. It is unnecessary to add on SPL for patients with satisfying sodium restriction, thus avoiding the adverse events of SPL. In patients with poor sodium restriction, supplementation of lowdose SPL might show a therapeutic benefit on lowering 24-h urine protein. The combination of short-term low-dose SPL and ARB is safe in patients with stage 1-3a CKD, but blood potassium must be carefully monitored.

\section{Abbreviations}

CKD: Chronic kidney disease; SPL: Spironolactone; eGFR: Estimated glomerular filtration rate; ESRD: End-stage renal disease; TGF: Transforming growth factor; RAAS: Renin-angiotensin-aldosterone system; ACEls: Angiotensin-converting enzyme inhibitors; ARBs: Angiotensin II receptor blockers; NSAIDs: Nonsteroidal anti-inflammatory medications; ALB: Albumin; PA: Pre-albumin; UA: Uric acid; TC: Total cholesterol; TG: Triglycerides; LDL-C: low density lipoproteincholesterol; CRP: C-reactive protein; Scr: serum creatinine; BUN: Blood urea nitrogen; 24h-UNa: 24-h urinary sodium; UK: Urine potassium; eDPI: Estimated dietary protein intake; SD: Standard deviation; ANOVA: Analysis of variance.

\section{Supplementary Information}

The online version contains supplementary material available at https://doi. org/10.1186/s12882-022-02711-z.

Additional file 1: Supplementary Table 1. Urine sodium excretion among the three groups at 12 weeks.

Additional file 2: Supplementary Table 2. Urinary sodium/creatinine ratio among the three groups at 12 weeks.

\section{Acknowledgments \\ None.}

\section{Authors' contributions}

$\mathrm{HZ}$ : Designed and participated in the main research content, including the formation of research ideas, the design of research programs, the resolution of key technical issues, data analysis, and data summary. BZ: Responsible for patient recruitment, clinical treatment, and observation, as well as assessment of the safety in the trial. LC: Responsible for patient recruitment, clinical observation, nutrition guidance, and follow-up. XY: responsible for data collection, patient education, and follow-up. RT: responsible for data collection, followup, and statistics. LH: responsible for data collection, follow-up, and statistical analysis. DY: responsible for patient enrollment and clinical observation. HC: 
responsible for patient enrollment and clinical observation. YW: responsible for patient enrollment and the solution of key technical issues. All authors have read and approved the manuscript.

\section{Funding}

This study was funded by the Hangzhou Science and Technology Committee [20130733Q15] and the Hangzhou Health Committee [2013Z07]. The funders had no role in study design, data collection, and analysis, decision to publish, or manuscript preparation.

\section{Availability of data and materials}

The datasets used and/or analyzed during the current study are available from the corresponding author on reasonable request.

\section{Declarations}

\section{Ethics approval and consent to participate}

The current study was approved by the ethics committee of Hangzhou Hospital of Traditional Chinese Medicine (2013LL065), and informed consent was obtained from the patients.

\section{Consent for publication}

Written informed consent to publish this information was obtained from study participants.

\section{Competing interests}

The authors declare that they have no competing interests.

Received: 3 September 2020 Accepted: 20 February 2022 Published online: 05 March 2022

\section{References}

1. Saran R, Robinson B, Abbott KC, Agodoa LYC, Bragg-Gresham J, Balkrishnan R, et al. US Renal Data System 2018 Annual Data Report: Epidemiology of Kidney Disease in the United States. Am J Kidney Dis. 2019;73:A7-8

2. Zhang L, Wang F, Wang L, Wang W, Liu B, Liu J, et al. Prevalence of chronic kidney disease in China: a cross-sectional survey. Lancet. 2012;379:815-22.

3. Vegter S, Perna A, Postma MJ, Navis G, Remuzzi G, Ruggenenti P. Sodium intake, ACE inhibition, and progression to ESRD. J Am Soc Nephrol. 2012;23:165-73.

4. McQuarrie EP, Traynor JP, Taylor AH, Freel EM, Fox JG, Jardine AG, et al. Association between urinary sodium, creatinine, albumin, and long-term survival in chronic kidney disease. Hypertension. 2014;64:111-7.

5. Habibi J, Hayden MR, Ferrario CM, Sowers JR, Whaley-Connell AT. Salt Loading Promotes Kidney Injury via Fibrosis in Young Female Ren2 Rats. Cardiorenal Med. 2014;4:43-52.

6. Varagic J, Ahmad S, Brosnihan KB, Habibi J, Tilmon RD, Sowers JR, et al. Salt-induced renal injury in spontaneously hypertensive rats: effects of nebivolol. Am J Nephrol. 2010;32:557-66.

7. Bernardi S, Toffoli B, Zennaro C, Tikellis C, Monticone S, Losurdo P, et al. High-salt diet increases glomerular ACE/ACE2 ratio leading to oxidative stress and kidney damage. Nephrol Dial Transplant. 2012;27:1793-800.

8. Park JS, Kim S, Jo CH, Oh IH, Kim GH. Effects of dietary salt restriction on renal progression and interstitial fibrosis in adriamycin nephrosis. Kidney Blood Press Res. 2014;39:86-96.

9. Heeg JE, de Jong PE, van der Hem GK, de Zeeuw D. Efficacy and variability of the antiproteinuric effect of ACE inhibition by lisinopril. Kidney Int 1989:36:272-9.

10. Vogt L, Waanders F, Boomsma F, de Zeeuw D, Navis G. Effects of dietary sodium and hydrochlorothiazide on the antiproteinuric efficacy of losartan. J Am Soc Nephrol. 2008;19:999-1007.

11. Slagman MC, Waanders F, Hemmelder MH, Woittiez AJ, Janssen WM, Lambers Heerspink $\mathrm{HJ}$, et al. Moderate dietary sodium restriction added to angiotensin converting enzyme inhibition compared with dual blockade in lowering proteinuria and blood pressure: randomised controlled trial. BMJ. 2011;343:d4366.
12. Funder JW. Minireview: Aldosterone and mineralocorticoid receptors: past, present, and future. Endocrinology. 2010;151:5098-102.

13. Funder JW. Aldosterone and mineralocorticoid receptors in the cardiovascular system. Prog Cardiovasc Dis. 2010;52:393-400.

14. Epstein M. Aldosterone blockade: an emerging strategy for abrogating progressive renal disease. Am J Med. 2006;119:912-9.

15. Duprez DA. Role of the renin-angiotensin-aldosterone system in vascular remodeling and inflammation: a clinical review. J Hypertens. 2006;24:983-91.

16. Duprez DA. Aldosterone and the vasculature: mechanisms mediating resistant hypertension. J Clin Hypertens (Greenwich). 2007;9:13-8.

17. Shibata S, Nagase M, Yoshida S, Kawachi H, Fujita T. Podocyte as the target for aldosterone: roles of oxidative stress and Sgk1. Hypertension. 2007:49:355-64.

18. Shibata S, Nagase M, Yoshida S, Kawarazaki W, Kurihara H, Tanaka H, et al. Modification of mineralocorticoid receptor function by Rac1 GTPase: implication in proteinuric kidney disease. Nat Med. 2008;14:1370-6.

19. Mundel P, Reiser J. Proteinuria: an enzymatic disease of the podocyte? Kidney Int. 2010;77:571-80.

20. Nagase M, Shibata S, Yoshida S, Nagase T, Gotoda T, Fujita T. Podocyte injury underlies the glomerulopathy of Dahl salt-hypertensive rats and is reversed by aldosterone blocker. Hypertension. 2006;47:1084-93.

21. Bomback AS, Klemmer PJ. The incidence and implications of aldosterone breakthrough. Nat Clin Pract Nephrol. 2007;3:486-92.

22. Bianchi S, Bigazzi R, Campese VM. Long-term effects of spironolactone on proteinuria and kidney function in patients with chronic kidney disease. Kidney Int. 2006;70:2116-23.

23. Furumatsu Y, Nagasawa Y, Tomida K, Mikami S, Kaneko T, Okada N, et al. Effect of renin-angiotensin-aldosterone system triple blockade on nondiabetic renal disease: addition of an aldosterone blocker, spironolactone, to combination treatment with an angiotensin-converting enzyme inhibitor and angiotensin II receptor blocker. Hypertens Res. 2008;31:59-67.

24. Selye H, Hall CE, Rowley EM. Malignant Hypertension Produced by Treatment with Desoxycorticosterone Acetate and Sodium Chloride. Can Med Assoc J. 1943:49:88-92.

25. Martinez DV, Rocha R, Matsumura M, Oestreicher E, Ochoa-Maya M, RoubsanthisukW, et al. Cardiac damage prevention by eplerenone: comparison with low sodium diet or potassium loading. Hypertension. 2002;39:614-8.

26. Hattori T, Murase T, Sugiura Y, Nagasawa K, Takahashi K, Ohtake M, et al. Effects of salt status and blockade of mineralocorticoid receptors on aldosterone-induced cardiac injury. Hypertens Res. 2014;37:125-33.

27. Coresh J, Selvin E, Stevens LA, Manzi J, Kusek JW, Eggers P, et al. Prevalence of chronic kidney disease in the United States. JAMA. 2007;298:2038-47.

28. O'Hare AM, Kaufman JS, Covinsky KE, Landefeld CS, McFarland LV, Larson EB. Current guidelines for using angiotensin-converting enzyme inhibitors and angiotensin II-receptor antagonists in chronic kidney disease: is the evidence base relevant to older adults? Ann Intern Med. 2009:150:717-24.

29. Abboud H, Henrich WL. Clinical practice. Stage IV chronic kidney disease. N Engl J Med. 2010;362:56-65.

30. Fisher ND, Hollenberg NK. Renin inhibition: what are the therapeutic opportunities? J Am Soc Nephrol. 2005;16:592-9.

31. Parving HH, Persson F, Lewis JB, Lewis EJ, Hollenberg NK, Investigators AS. Aliskiren combined with losartan in type 2 diabetes and nephropathy. N Engl J Med. 2008;358:2433-46.

32. Rettig RA, Norris K, Nissenson AR. Chronic kidney disease in the United States: a public policy imperative. Clin J Am Soc Nephrol. 2008;3:1902-10.

33. Levey AS, Atkins R, Coresh J, Cohen EP, Collins AJ, Eckardt KU, et al. Chronic kidney disease as a global public health problem: approaches and initiatives - a position statement from Kidney Disease Improving Global Outcomes. Kidney Int. 2007;72:247-59.

34. Maroni BJ, Steinman TI, Mitch WE. A method for estimating nitrogen intake of patients with chronic renal failure. Kidney Int. 1985;27:58-65.

35. Nishimoto M, Ohtsu H, Marumo T, Kawarazaki W, Ayuzawa N, Ueda K, et al. Mineralocorticoid receptor blockade suppresses dietary saltinduced ACEI/ARB-resistant albuminuria in non-diabetic hypertension: a sub-analysis of evaluate study. Hypertens Res. 2019;42:514-21.

36. Shibata S, Ishizawa K, Uchida S. Mineralocorticoid receptor as a therapeutic target in chronic kidney disease and hypertension. Hypertens Res. 2017:40:221-5. 
37. Ghazi L, Dudenbostel T, Lin CP, Oparil S, Calhoun DA. Urinary sodium excretion predicts blood pressure response to spironolactone in patients with resistant hypertension independent of aldosterone status. J Hypertens. 2016;34:1005-10.

38. De Nicola L, Minutolo R, Chiodini P, Zoccali C, Castellino P, Donadio C, et al. Global approach to cardiovascular risk in chronic kidney disease: reality and opportunities for intervention. Kidney Int. 2006;69:538-45.

39. Van Zuilen AD, Wetzels JF, Bots ML, Van Blankestijn PJ, Group MS. MASTERPLAN: study of the role of nurse practitioners in a multifactorial intervention to reduce cardiovascular risk in chronic kidney disease patients. J Nephrol. 2008;21:261-7.

40. Kutlugun AA, Arici M, Yildirim T, Turgut D, Yilmaz R, Altindal M, et al. Daily sodium intake in chronic kidney disease patients during nephrology clinic follow-up: an observational study with 24-hour urine sodium measurement. Nephron Clin Pract. 2011;118:c361-6.

41. Kang SS, Kang EH, Kim SO, Lee MS, Hong CD, Kim SB. Use of mean spot urine sodium concentrations to estimate daily sodium intake in patients with chronic kidney disease. Nutrition. 2012;28:256-61.

42. Krikken JA, Laverman GD, Navis G. Benefits of dietary sodium restriction in the management of chronic kidney disease. Curr Opin Nephrol Hypertens. 2009;18:531-8.

43. Chrysostomou A, Pedagogos E, MacGregor L, Becker GJ. Double-blind, placebo-controlled study on the effect of the aldosterone receptor antagonist spironolactone in patients who have persistent proteinuria and are on long-term angiotensin-converting enzyme inhibitor therapy, with or without an angiotensin II receptor blocker. Clin J Am Soc Nephrol. 2006;1:256-62.

44. van den Meiracker AH, Baggen RG, Pauli S, Lindemans A, Vulto AG, Poldermans D, et al. Spironolactone in type 2 diabetic nephropathy: Effects on proteinuria, blood pressure and renal function. J Hypertens. 2006;24:2285-92.

45. Rossing K, Schjoedt KJ, Smidt UM, Boomsma F, Parving HH. Beneficial effects of adding spironolactone to recommended antihypertensive treatment in diabetic nephropathy: a randomized, double-masked, crossover study. Diabetes Care. 2005;28:2106-12.

46. Schjoedt KJ, Rossing K, Juhl TR, Boomsma F, Rossing P, Tarnow L, et al. Beneficial impact of spironolactone in diabetic nephropathy. Kidney Int. 2005;68:2829-36.

47. Epstein M, Williams GH, Weinberger M, Lewin A, Krause S, Mukherjee $\mathrm{R}$, et al. Selective aldosterone blockade with eplerenone reduces albuminuria in patients with type 2 diabetes. Clin J Am Soc Nephrol. 2006;1:940-51.

48. Lyubarova R, Gosmanova EO. Mineralocorticoid Receptor Blockade in End-Stage Renal Disease. Curr Hypertens Rep. 2017;19:40

49. Pitt B, Zannad F, Remme WJ, Cody R, Castaigne A, Perez A, et al. The effect of spironolactone on morbidity and mortality in patients with severe heart failure. Randomized Aldactone Evaluation Study Investigators. $N$ Engl J Med. 1999;341:709-17.

50. Pitt B, Remme W, Zannad F, Neaton J, Martinez F, Roniker B, et al. Eplerenone, a selective aldosterone blocker, in patients with left ventricular dysfunction after myocardial infarction. N Engl J Med. 2003;348:1309-21.

51. Bakris GL, Agarwal R, Anker SD, Pitt B, Ruilope LM, Rossing P, et al. Effect of Finerenone on Chronic Kidney Disease Outcomes in Type 2 Diabetes. N Engl J Med. 2020;383:2219-29.

\section{Publisher's Note}

Springer Nature remains neutral with regard to jurisdictional claims in published maps and institutional affiliations.

Ready to submit your research? Choose BMC and benefit from:

- fast, convenient online submission

- thorough peer review by experienced researchers in your field

- rapid publication on acceptance

- support for research data, including large and complex data types

- gold Open Access which fosters wider collaboration and increased citations

- maximum visibility for your research: over 100M website views per year

At BMC, research is always in progress.

Learn more biomedcentral.com/submissions 